
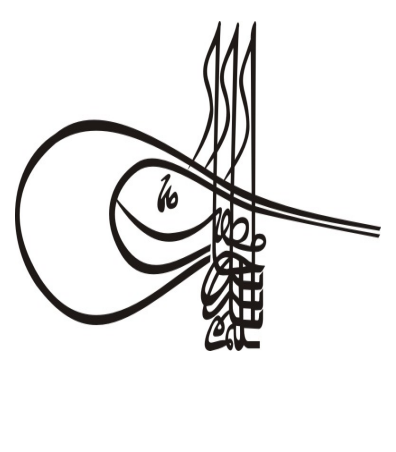

Received/Geliș: 29.10.2019

\section{Turkísh Shtuðíes \\ Comparative Religious Studies \\ Volume 14 Issue 4, 2019, p. 577-589 \\ DOI: $10.29228 /$ TurkishStudies. 39523 \\ ISSN: 2667-5544 \\ Skopje/MACEDONIA-Ankara/TURKEY

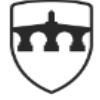 \\ INTERNATIONAL \\ BALKAN UNIVERSITY \\ EXCELLENCE FOR THE FUTURE IBU.EDU.MK}

\author{
Research Article / Araştırma Makalesi \\ Article Info/Makale Bilgisi
}

$\checkmark$ Accepted/Kabul: 20.12.2019

\title{
MÛSULLU BİR MUHADDİS VE SAHÎH HADİS BULUNMAYAN KONULARA DAİR BİR ÇALIŞMASI: ÖMER B. BEDR el-MEVSILÎ ve el-MUĞNî ADLI ESERİ.
}

\author{
Nurullah AGITTOĞLU*
}

\begin{abstract}
öz
Hz. Peygamber'e (sas) ait olmayan sözlerin onun ağzından uydurulması, yapmadığı veya onaylamadığı bir davranışın kendisine izafe edilmesi sonucu ortaya çıkan rivayetlere mevzû hadis denmektedir. Bir rivayetin mevzû olduğu bâtıl ve masnû kelimeleriyle de ifade edilmektedir. Mevzû hadisler muhaddisler tarafından çeşitli metotlarla bir araya getirilmiştir. İbnü'l-Kayserânî'nin Tezkiretü'l-mevzûât'l, Cûzekanî'nin el-Ebâtîl ve'l-menâkîr ve's-sihâh ve'l-meşâhîr'i, Ebû'l-Ferec İbnü'l-Cevzî'nin el-Mevzûât'l, Suyûtî'nin kaleme aldığı el-Leâli'l-masnûa fi'l-ehâdîsi'l-mevzûa'sl, İbn Arrâk'in Tenzîhü'ş-şerîati'l-merfûa ani'lahbâriş-şenîati'-mevzûa'sı vb. eserler bu alanda öne çıkan teliflerdir. Bu literatürde yazılmış önemli bir eser de el-Muğnî ani'l-hifzi ve'l-kitâb adlı eserdir. Müellifinin tam adı Ebû Hafs Ziyâüddîn Ömer b. Bedr b. Saîd elMevs1lî (ö. 622/1225) olup kendisi muhaddis ve Hanefî fakîhidir. 557/1162'de Mûsul'da doğan Mevsilî'nin lakabının Safiyyüddin, nisbelerinin de Verrânî, Hanefî olduğu belirtilmiștir. Eğitimini Bağdat’ta sürdüren Mevs1lî, Ebû'l-Ferec İbnü'l-Cevzî gibi âlimlerden yararlanmıştır. Halep, Dımaşk, Kudüs gibi ilim merkezlerinde hadis rivayet etmiş ve ömrü boyunca âlimlerden faydalanmayı sürdürmüş olan Mevsıllî'den de birçok kimsenin rivayette bulunduğu ifade edilmiştir. Onun hadis ve diğer alanlarda başka eserleri bulunmaktadır. Çalışmamızın konusu olan el-Muğnî adlı eserinde hadislerin sened ve metinlerini zikretmeden, hangi konularda sahih hadislerin bulunmadiğı veya hangi konularda $\mathrm{Hz}$. Peygamber'den (sas) rivayet gelmediğini belirtmiștir. Müellifin, ögrencilere ve hadisle iştigal etme şansı bulamamıs meslek sahiplerine kısaca bilgi vermek ve onları hadise yönlendirmek için seçtiği bu metot
\end{abstract}

\footnotetext{
- Bu çalışma 27-29 Nisan 2018 tarihleri arasında düzenlenen 1. Uluslararası Zap Havzası Uleması Sempozyumu'nda yazar
} tarafından sunulan tebliğin geliştirilmiş ve makale formatına getirilmiş halidir. 
bazı âlimler tarafından isabetsiz diye nitelendirilerek ciddi anlamda eleştirilmiştir. Bu çalışmamızda Mevsılî'nin, özellikle mukaddime kısmında Muhammed Hıdır et-Tûnusî tarafından mevzû hadisler ile ilgili faydalı ve geniş malumat sunulan el-Muğnî adlı eseri çerçevesinde mevzû hadislere yaklaşımı, takip ettiği metot ve kendisine yöneltilen eleştiriler üzerinde durulacak ve gerekli görülen değerlendirmeler yapılmaya çalışılacaktır.

Anahtar Kelimeler: Hz. Peygamber, Mevzu hadis, Mevsılî, elMuğni.

\title{
A MUHADDITH FROM MOSUL AND HIS STUDY ON MEVZU HADITHS: OMAR B. BEDR Al-MAVSILI AND HIS STUDY el- MUGNI
}

\begin{abstract}
The words that are not belonging to the Prophet are made up from his mouth and the result is called Mevzu Hadith. It is also expressed by the vagueness and masni words that a narrative is in place. The corresponding hadiths have been gathered by muhaddis with various methods. Ibn al-Kayserani's Tezkiretu'l-mevzuât, Cuzekanî's al-Ebâtîl ve'l-menâkîr ve's-sıhâh ve'l-meşahîr, Abu'l-Ferec Ibn al-Jawzi's alMevzûât, al-Leâli'l-masnûa fi'l-ehâdîsi'l-mevzûa, which Suyuti received, and Ibn Arrâk's Tenzîhü'ş-şerîati'1-merfûa ani'1-ahbāriş-şenîa, etc. artifacts are the outstanding copyrights on this scene. An important work written in this literature is al-Muğnî ani'l-hıfzi ve'l-kitâb. The full name of the author is Abu Hafs Ziyâüddîn Ömer b. Bedr b. Said al-Mawsili (d. $622 / 1225)$ and himself is the muhaddis and Hanafi clergyman. $557 / 1162$ in Mosul was named Safiyyuddin of the name of the Mevsilî, Verrânî, Hanafi is stated. Mevsili, who continued his education in Baghdad, also benefited from scholars such as Abu'l-Ferec Ibn al-Jawzi. In the centers of science such as Aleppo, Damascus and Jerusalem, Hadith has been narrated and it is stated that there are many rivayades among Mevsilî who continued to benefit from scholars throughout his life. His hadith and other fields also have other works. In the work of al-Muğnî which is the subject of our study, we do not mention the texts of the hadiths and on which topics there are not any sahih hadiths or in which subjects He said that he did not come from the Prophet. This method, which the writer chose to give brief information to the students and professional owners who had no chance to engage in hadith, and to direct them, was seriously criticized by some scholars as being uneducated. In this work, we will focus on the approach to Mevzu Hadiths, the method followed by him, and the criticisms directed to him in the framework of al-Muğnî, which is a useful and extensive information on Hıdır et-Tûnusî, especially in his verses.
\end{abstract}

\section{STRUCTURED ABSTRACT}

There are two basic sources of Islamic religion: the Qur'an and the Sunnah. Hadiths of the Prophet has an important function for the 
understanding of religion. Muslims emphasized learning, teaching and practicing hadiths. Hadith studies have emerged and developed for this purpose. One of the most important events in hadith science is hadith methodology. There are various and important sub-titles in the science of hadith methodology. The subject of mevzu hadith is very important in usul al-hadith. This issue has always been on the agenda since the early days. This issue is closely related to the issue of the identification of hadiths, the second main source of religion. The problem of finding goodness is a matter of sorting out those who have already been made up of hadiths and keeping them away from such a suspicion. As they have been devoted to this subject in the books of Muhaddiths, which are meticulously working, a literature has emerged by writing independent works in this area. To praise imams they follow, including their political members, their religious sects, their tribes, their tongues, their borders and their followers, to earn rankings in the hands of administrators, to be enthusiastic in community and mosques, as the enemies of religion have faked the enemies of religion, liars and ignorers for the purpose of raising their rivalry against the rivers, and then adding to this fabricated things the names of the hadiths of the well-known hadiths to raise their ranks.

The words of the lie that they accused the Prophet (sas) with slander were mentioned. This definition carries a wide range of features, including the causes of hadith falsification. The most important reason why the anti-Islamists in the Prophet's life do not dare to invent hadith in his name is that this kind of blasphemy is the idea that he will soon lie. Moreover, it is certain that in his various hadiths some of the liars will come forth, and those who know that they will make a lie in their own way will be helpless and warn the soldier that it will prevent the appearance of the liars in that period. Companions have been very meticulous in this regard. This meticulousness of Ashab has prevented the establishment of a suitable floor for the hadith.

The hadith-making movement began and developed in a period of depression, the beginning of the devolution of the age of the saha and the great descendants. The subject of my work is al-Muğnî ani'l-hıfzi ve'lkitâb. The text of the hadiths and the synods are not mentioned and in which subjects there are not any authentic hadiths. It is stated that the rumor does not come from the Prophet. This method, which the writer chose to provide information to the students and to those who could not find an opportunity to deal with the hadith, and to direct them, was accused by many scholars of having ridiculous and irresponsible judgment on these matters, since he had to have a wide range of hadith cults, and Ibn Hajjar. He said that Ibn al-Jawzi had benefited from the Kitâb al-Mevzuât and did not add anything to him. Muhammed Hıdır alTûnusî prepared a mukaddime and ta'lik. Tûnusî, who presented extensive information on the related hadiths in his account of about 11 pages, seems to have targeted the passage of the material after making the necessary sub-structure about the subject. Mevsili has arranged his work in the form of 101 babs. The author has made his own assessment. Sometimes, instead of making an assessment, another scholar is content to convey what he has done. In my work, which is the subject of my work, the texts and sened are not mentioned in which topics there are not authentic hadiths. He says that the narration does not come from the 
Prophet. This method, which the writer chose to give brief information to the students and those who can not find the opportunity to deal with hadiths and direct them to the events, is striking.

The author noted in practice that he did not go back repeatedly, stating that he intends to present information without unwittingly, and distinguished his work with babs. It has not neglected to formulate the aim of "the lesser one tastes, the more towards ones". Abu Hatim al-Razi, Abu Cafer al-Ukaylî, Ahmed b. Hanbal, Ibn al-Mubarak, Ibn al-Jawzi, Ishaq b. Ibrahim al-Hanzali, Tirmidhi, Abu Zur'a, Bukhari, Dârekutnî, Ibn al-Medini, Hakim, al-Azdi, Abdullah al-Ansari and so on. There are many examples in which scholars.

Keywords: The Prophet, Mevzû, Mawsılî, al-Muğnî.

\section{Giriş}

İnsan, iyi yönleri ve zaaflarıyla birlikte yaratılmıştır. Bu durum, onun sorumlu bir varlık olması ile yakından ilgilidir. Fitratının zaaflarından uzak durması gerekiyorsa da bu, her zaman kolay olmamaktadır. İşte olayları olduğundan farklı göstermek, kendilerine sevgi, saygı ve sempati beslenen şahısları aşırı ifadelerle övmeye çalışmak da insan fitratının zaaflarındandır. $\mathrm{Bu}$ tarz hareketlerin çoğu zaman maddi ve manevi bazı hesaplar için yapılması da bu zaafiyetin sonucu ortaya çıkmaktadır. Kişiyi yalancı durumuna sokan bu sıfatın mevzû hadislerin doğup gelişmesinde etkisi olduğu bir gerçektir. (Kandemir, 1997: 11) Dolayısıyla mevzû hadislerin doğuşunda insanî zaaflar, değişik amaç ve kaygıların etkisinin olduğu inkâr edilemez.

Hadis usûlü ilminde mevzû hadis konusu oldukça önemlidir. (Bkz. İbnü's-Salâh, Trs.: 98; Suyûtî, 1431: II, 423; İbn Hacer, 2001: 107; Koçyiğit, 1967: 132) İlk dönemlerden itibaren bu konu hep gündemde tutulmuştur. Zira bu konu, dinin ikinci ana kaynağı olan hadislerin tespiti meselesi ile yakından ilgili olmuştur. Sıhhatin tespit edilmesi sorunu zaten hadislerden uydurulmuş olanları ayıklama ve onları böyle bir şüpheden uzak tutma gayesi taşımaktadır. Nitekim Hadis usûlünün doğuşuna etki eden en önemli faktörler içerisinde mevzû hadislere karşı önlem alma gayesinin bulunduğunu söylemek mümkündür.

Talat Koçyiğit mevzû hadisin kapsamlı bir tanımını şu şekilde yapmaktadır: "En başta zındıklar olmak üzere, mensup oldukları siyasi firkaları, fikhi mezhepleri, kabilelerini, cinsiyetlerini, dillerini, beldelerini, takip ettikleri imamlarını övmek, yönetici ve idarecilerin nezdinde mertebeler kazanmak, câmi ve mescidlerde va'zettikleri cemaatin teveccühüne nâil olmak, halkın, dini emir ve nehiylere karşı rağbetini artırmak maksadıyla din düşmanlarının, yalancıların ve cahillerin uydurdukları, sonra bu uydurulan şeylere, derecelerini yükseltmek için tanınmış hadis râvilerinden düzdükleri isnâdlar ekleyerek hadismiş gibi, Hz. Peygamber'e (sas) iftira ile isnad ettikleri yalan sözlere mevzu denilmiştir”. (Koçyiğit, 1967: 132.) Bu tanım hadis uydurma sebeplerini de içinde barındıran geniş bir özellik taşımaktadır.

Mevzû hadislerin, Hz. Peygamber'le bir ilgisi olmadığı için, bunlar, hadislerin taksimiyle ilgili bölümlerde yer almamıştır. Her ne kadar hadisçiler arasında, bu çeşit sözlere hadis denilmişse de, sadece onların metin ve isnâd yönünden (şeklen) hadise benzemeleri sebebiyledir. (Koçyiğit, 1967: 132) Ancak Emîr es-San'ânî (ö. 1182/1768), mevzû hadisleri zayıf hadislerin en kötüsü kabul eden muhaddislere itiraz etmiş, Peygamber adına uydurulan sözlerin gerçek hadislerle bir ilgisi bulunmadığından onları hadis kelimesiyle nitelemenin doğru olmadığını belirtmiştir. Bir rivayetin mevzû olduğu bâtıl, muhtelak ve masnû kelimeleriyle de ifade edilmekte, hadis uyduran kimseye vaddâ‘ denmektedir. (Kandemir, 2004b: 493) Mevzû hadis konusu hadisçilerin en hassas oldukları 
ve adetâ taviz vermedikleri bir alan hüviyetindedir. Muhaddislerin amaçları, dinin ikinci ana kaynağının korunması olduktan sonra, durumun böyle olması kaçınılmazdır.

Hz. Peygamber'in sağlı̆̆ında İslâm aleyhtarlarının onun adına hadis uydurmaya cesaret edememelerinin en önemli sebebi bu tür iftiraları onun hemen yalanlayacağı düşüncesidir. Zira o hayatta olup, kendisine izafe edilen bir sözün ona sorulması, teyit ettirilmesi imkânı bulunmaktaydı. Ayrıca onun muhtelif hadislerinde ileride birtakım yalancıların ortaya çıkacağını, kendi ağzından yalan uydurma işini bilerek yapanların cehenneme gireceğini (Buhârî, "İlim", 38) söyleyerek ashabını uyarmasının da, o devirde yalancıların ortaya çıkmasını engellediği muhakkaktır. Sahâbe de bu konuda çok titiz davranmıştır. Ashabın bu titizliği, hadis uydurmaya uygun bir zeminin doğmasını önlemiştir. Hadis uydurma hareketi, sahâbe asrının sonu ve büyük tâbiîler devrinin başlangıcı olan buhranlı bir devirde başlayıp gelişmiştir. (Kandemir, 2004b: 493) Hz. Peygamber' in hayatta olmadığı, fitnenin başlayıp yayıldığı, değişik kültürler ve milletlerin Müslümanlarla karşılaşma imkânı bulduğu böyle bir dönemde farklı gaye ve kaygılarla hadis uydurma işinin başlamış olması dikkat çekmektedir.

Titiz bir şekilde çalışan muhaddisler, usûl kitaplarında bu konuya önemle yer verdikleri gibi, bu alanda müstakil eserler kaleme almak suretiyle de bir edebiyat ortaya çıkarmışlardır.

Mevzû hadisler muhaddisler tarafından çeşitli metotlarla bir araya getirilmiştir. (Geniş bilgi için bkz. Kandemir, 2004b: 495-496) Hadisçiler Müslümanları bu konuda aydınlatma ve bilinçlendirmeyi kendilerine görev bilmişlerdir. İşte bu amaçla ve bilinçle sözkonusu alanda birçok esere imza atılmıştır. Bu eserlerden bir tanesi de makalemizin konusu olan Mevsılî’nin (ö. 622/1225) el-Muğnî ani'l-hıfzi ve'l-kitab adlı çalışmasıdır.

\section{Mevsılı̂’nin Kısaca Hayatı ve El-Muğnî Adı Eseri}

Tam adı Ebû Hafs Ziyâüddîn Ömer b. Bedr b. Saîd olan ve çalışmada kendisinden -kısaca nisbesiyle- Mevsılî (ö. 622/1225) diye bahsedeceğimiz müellifimiz, Hanefî mezhebinde fakih kabul edilen bir âlim olup aynı zamanda muhaddistir. Hicri 557'de (m. 1162) Mûsul'da (bkz. Belâzûrî, 1987, s. 463 vd. ) doğan Mevsılî, kıraat âlimi Muhammed b. Mübârek el-Halâvî, Ebü’l-Ferec İbnü'lCevzî gibi âlimlerden istifade etmiştir. Halep, Dımaşk, Kudüs gibi ilim merkezlerinde hadis rivayet etmiş ve hayatını âlimlerden ilim alarak sürdürmüştür. Kendisinden İbnü’l-Adîm ile kızı Şühde, Reşîd el-Attâr ve Ebü'l-Mehâsin Yûsuf b. Ahmed el-Yağmurî ve başkaları rivayette bulunmuşlardır. Mevsılî 28 Ramazan 622'de (3 Ekim 1225) Dımaşk'ta Nûriyye Bîmâristanı'nda vefat etti. Ölüm tarihinin 623 olduğu da söylenmiştir. (Mevsılî, 1342: 16 Musannıfın özgeçmişi; Kandemir, 2004a: 488-489.)

\section{Eserleri:}

1. el-Cem' beyne's-Sahîhayn maa hazfi's-senedi ve'l-mükerrer mine'l-beyn. Mevs1lî, halkın hadislere çok ilgi göstermemesini gerekçe göstererek yazdığını söylediği bu eserde Buhârî ile Müslim'in el-Câmiu's-sahîh'lerinde bulunan 2874 rivayeti bir araya getirmiş, yalnız sahâbî râvilerini kaydetmiş, aynı konuda muhtelif sahâbîler tarafından rivayet edilen hadislerin sadece birini almış, uzun rivayetlerde Hz. Peygamber'e (sas) ait olmayan ifadeleri ihtisar etmiş ve hadisleri konularına göre alfabetik olarak sıralamıştır. çalışmıştır.

2. el-Vukûf ale'l-mevkûf. Müellif bu kitapta 151 mevkuf rivayetin sihhat derecesini tespite

Müellifin diğer eserleri arasında el-Akîdetü's-sahîha fi'l-mevzûâti's-sarîha, İstinbâtu'l-maîn mine (fi) 'l-ileli ve't-târîh li'bni Maîn, İhtiyâru ahyâri'l-ahbâr, el-İntisâr ve't-tercîh li-mezhebi'ssahîh, el-Asabiyyetü'l-mezhebiyyetü'l-makîte adlı çalışmaları bulunmaktadır. (Mevsılî, 1342: 16 Müellifin özgeçmişi; Katip Çelebi, Trs.: II, 1158; Kandemir, 2004a: 488-489.) 
Çalışmamıza konu olan eseri ise el-Muğnî ani'l-hıfzi ve'l-kitâb adlı çalışmasıdır. Müellif, eserin başında mevzû hadislerle ilgili başka çalışmalarının da bulunduğunu ve kendisinden önce buna benzer çalışmalar yapanların bulunmadığını belirtmiştir. (Mevsılî, 1342: 4) Burada müellif, sahih hadis bulunmayan konuların tespitine yönelik olarak kendisinden önce eser verilmediğini kastetmiş olmalıdir.

Eserde hadislerin sened ve metinleri zikredilmeden hangi konularda sahih hadislerin bulunmadığ veya hangi konularda Hz. Peygamber'den (sas) rivayet gelmediği belirtilmektedir. Müellifin, öğrencilere ve hadisle ilgilenme firsatı bulamayan ve çalışan kişilere kısaca bilgi vermek ve onları hadise yönlendirmek için seçtiği bu metot pek geniş bir hadis kültürüne sahip olmayı gerektirdiğinden, kendisi birçok âlim tarafından bu konularda acele ve isabetsiz hüküm vermekle suçlanmış, İbn Hacer el-Askalânî de sadece İbnü'l-Cevzî' nin Kitâbü 'l-Mevzûât'ından faydalandığını ve ona bir şey katmadığını söylemiştir. (İbn Hacer, 1401: 20; Kandemir, 2004a: 488-489.)

Zeynüddin el-Irâkî ve Şemseddin es-Sehâvî'nin de tezatlar taşıdığını söyleyerek eleştirdikleri eseri Hüsâmeddin el-Kudsî Intikâdü'l-Muğnî adlı çalışmasıyla (Dımaşk, 1343) tenkit etmiştir. Mevsılî'nin el-Muğnî̀'de verdiği bilgilerin üçte birini eleştirdiğini söyleyen Ebû İshak elHuveynî el-Eserî ise önce bu kitabın muhtevasına yönelik tenkitlerini 101 konuda toplayarak Cünnetü'l-mürtâb bi-naķdi'l-Muğnî ani'l-hifzi ve'l-kitâb isimli eserini kaleme almış daha sonra da bunu ihtisar ederek ilk kitabındaki eleştirilerini yirmi sekiz konuda özetlemiştir. (el-Eserî, 1994, s. 9). Eserî, bu çalışmalarında genel değerlendirmeleri tahlil etmiş, geniş araştırmalarıyla yazarı tenkit etmiş ve sahih hadis yoktur denilen konularda sağlam hadisler bulunduğunu ortaya koymaya çalışmıştır. (Yıldırım, 2017: 19)

Mevsılî’nin takip ettiği yöntemle ortaya konan eserleri tenkit eden âlimlerin de tenkit amaçlı çalışmalarında bir eksiklik olduğu belirtilmiştir. Buna göre, bu eserleri tenkit edenler, hadis kaynaklarında sağlam senedlerle aktarılan hadisleri delil gösterip, tenkit ettikleri kitapların yanıldıklarını ispatlamaya çalışırlar. Oysa belli konularda sahih hadis yoktur diyenler, onların gördüğü hadisleri zaten incelemiş̧lerdir. Onları bu rivayetleri sahih kabul etmemeye götüren anlayışın tenkit eden yazarlarca fark edilmediği görülmektedir. Bunların tenkitleri senedlere bağımlı kalan çalışmalar olmaktan öteye geçmemiştir. Değişik temel hadis kaynaklarındaki bazı hadisleri tenkit eden bu âlimlerin metin tenkidini başarıyla yaptıkları, sonrakilerin ise onların seviyesine ulaşamadığı belirtilmiştir. (Yıldırım, 2017: 19-Açıklama dipnotu-)

Muhammed Hıdır et-Tûnusî esere bir mukaddime ve ta'lik hazırlamıştır. Yaklaşık 11 sayfa tutan mukaddimesinde mevzû hadisler ile ilgili geniş malumat sunan Tûnusî, konuyla ilgili gerekli alt yapıyı oluşturduktan sonra esere geçilmesini gayet isabetli bir şekilde hedeflemiş görünmektedir. (Mevs1lî, 1342: 4-14 Mukaddime)

Mukaddimede özetle İslam'a zarar vermek isteyen bazı sefihlerin hadise yönelerek hadis uydurma işine giriştikleri, bu uydurma işini özellikle zındıkların yaptığı, yöneticilere yakın olmak isteyen kimi insanların da bu işe girdikleri, bazı milletleri ve kavimleri zemmeden veya onları öven rivayetlerin de uydurulduğu hususu, örnekleri ile sunulmaktadır. Ticareti veya alışverişine katkı sağlamak amaciyla hadis uyduranlar, şöhret peşinde olup sözlerinin dinlenilmesi gayesini güdenlerin yanında bu uydurma işini sevap kazanma düşüncesi ile dine fayda sağlama iddiasından hareket ederek yapanlar da ortaya çıkmıştır. Bu örneklerin yanı sıra bazen râvîlerin tesebbütünün azlığından farkında olmadan bu uydurma işine ortak oldukları da vurgulanmıştır. (Mevsılî, 1342: 4-14 Mukaddime)

Hz. Peygamber'in kendisine yönelik yalan ve iftiranın tehlikesini öngörebildiği için "men kezebe..." hadisini (Buhârî, "İlim", 38; Muslim, "Mukaddime", 3, 4; Ebû Dâvûd, "İlim", 4) buyurduğuna dikkat çekilen mukaddimede, bu hadisin 100'den fazla sahâbî tarafından rivayet edildiği ve aşere-i mübeşşere'nin üzerinde ittifak ettiği tek hadis olduğu noktası da vurgulanmıştır. 
(Mevsılî, 1342: 4-14 Mukaddime) Devamında da mevzû hadis konusu detaylı bir şekilde çok yönlü olarak ortaya konmaya çalışılmıştır.

Mukaddimeden hemen sonra müellifin metodu hakkında önemli bir ayrıntıya dikkat çeken Tûnusî, kitapta ل ل ل إصح ve lafızlarının mevzû hadis anlamında kullanıldığını belirtmiş, buna benzer kullanımların bazı muhaddislerin ıstılahında yer aldığını vurgulayarak Zerkeşî’yi örnek vermiştir. (Mevsılî, 1342: 15; Ayrıca bkz. Uğur, 1992: 196)

\section{Mevsılı̂’nin El-Muğnî Adlı Eseri Üzerine Bazı Değerlendirmeler}

Hadis uleması, yorucu gayretler neticesinde çeşitli konularla alakalı hadis rivayetlerini inceleme altına almışlar, ulaştıkları genel kanaatleri bazen müstakil eserlerinde bazen de çalışmalarına serpiştirdikleri açıklamalarla ortaya koymuşlardır. Bu izahatlarda geçen, herhangi bir konudaki hadislerin tamamının sahih olmadığı veya mevzû olduğu şeklindeki değerlendirmeler, hadis araştırmacılarına genel bir bakış açısı kazandırmıştır. (Yıldırım, 2017: 15) Bu tür çalışmalar, bir konuyla ilgili hadis rivayetlerini araştıırken veya bu tür rivayetleri ders, vaaz vb. etkinliklerde kullanırken, kişilerin daha dikkatli ve temkinli hareket etmesini sağlamaya yardımcı olmuştur.

el-Muğnî adlı eserinde Mevsılî, hadislerin sened ve metinlerini zikretmeden, hangi konularda sahih hadislerin bulunmadığı veya hangi konularda Hz. Peygamber'den rivayet gelmediğini belirtmiştir. Müellifin, öğrencilere ve hadisle iştigal etme şansı bulamamış meslek sahiplerine kısaca bilgi vermek ve onları hadise yönlendirmek için seçtiği bu metot ilginçtir. Müellifin pratik olarak, kestirmeden bilgi sunmayı amaçladığı belirtilerek tekrarlara girmediği ve eserini bablara ayırdığı girişte belirtilmiştir. O, "Az olanın tadına varan, çok olana yönelir" şeklinde amacını formüle etmeyi de ihmal etmemiştir. (Mevsılî, 1342, s. 18)

Mevsılî, eserini 101 bab şeklinde düzenlemiştir. İlk bab imanın artması ve eksilmesi konusunda olup, sonra Mürcie, Cehmiyye, Kaderiyye ve Eş'ar'iye hakkındaki bab gelmektedir. Kelamullah'ın mahlûk olmadığı, Meleklerin yaratılışı, Muhammed ve Ahmed isimlendirmeleri, Akıl, İlmin farziyeti, Fezailü'l-Kur'an, Hz. Ebubekir'in fazileti, Arap kabilelerin fazileti şeklinde konular devam etmektedir.

İmanın artıp eksilmesi ile ilgili babın tam adı "Bâbun fî̀ ziyâdeti'l-imân ve noksanihi ve ennehu kavlun ve amel" şeklindedir. Ardından da müellif, "Kâle'l-musannıf: Lâ yasıhhu fî hâze'lbâb an Resûlillah şey'ün -bu babda Resûlullah'tan sahih bir hadis bulunmamaktadır-" ifadesini kullanarak değerlendirmesini yapmıştır. (Mevsılî, 1342: 19) Kelam tartışmalarının yaşandığı bir zamanda bazen bir fırka imanın artmasıyla ilgili, diğer bir firka ise tersi yönde hadisler uydurma yoluna gitmiş̧lerdir. (Yıldırım, 2017, s. 21) Bu yönüyle müellifin, kitabına böyle babla başlamış olması dikkate değerdir.

Bazen değerlendirme yapmak yerine başka bir âlimin yaptı̆̆ değerlendirmeyi nakletmekle yetinmektedir. Örneğin Allah kelamının kadim olup gayrı mahlûk olduğu ile ilgili babda İbnü’lCevzî'nin değerlendirmesini aktarmaktadır: "Kad verede fî hâze'l-bab ehâdisu leyse fîha şey'ün sebete anhu - Bu babda varid olan bazı rivayetler var ise de Hz. Peygamber'e ait oluşlarına dair bir tespit ve delil bulunmamaktadır. (Mevsı11̂, 1342: 20)

Bazen de rivayeti nakleder, ancak o rivayetin mevzû olduğu kaydını ekler. Örneğin meleklerin yaratılışı ile ilgili şöyle bir rivayeti aktarır: "Cebrail her sabah nur denizine dalar. 70 bin damla su alır. Allah her damladan bir melek yaratır." Devamında, bu hadisin tarikleri olduğunu, ancak bu konuda ne Hz. Peygamber'den ne de başka birinden sahih bir haber gelmediğini belirtmiştir. (Mevsılî, 1342: 20)

Mevsılî’nin genel olarak takip ettiği metodu Yıldırım şöyle özetlemektedir:

“a. Bab ismi verip altında rivayet zikretmeden, bu konuda sahih hadis yoktur demektedir. 
b. Bab ismi verip altında bir hadisçinin o konuyla ilgili sahih bir rivayet bulunmadığına dair sözünü nakletmektedir.

c. Bazen bab başlığından sonra bir hadis zikretmekte, o ve benzeri hadislere dair hükmünü vermektedir.

d. Bazen de bab isminden sonra bu konuda sahih hadis yoktur demekte, istisnaları varsa onları zikretmektedir." (Yıldırım, 2017, s. 18)

Ebû Hâtim er-Râzî, Ebû Cafer el-Ukaylî (ö. 322/934), Ahmed b. Hanbel (ö. 241/855), İbnü'lMübarek (ö. 181/979), İbnü'l-Cevzî (ö. 597/1201), İshâk b. İbrahim el-Hanzalî (ö. 238/853), Tirmizî (ö. 279/892), Ebû Zür'a (ö. 264/878), Buhârî (ö. 256/870), Dârekutnî (ö. 385/995), İbnü'l-Medinî (ö. 234/848), Hâkim (ö. 405/1014), el-Ezdî (ö. 374/985), Abdullah el-Ensârî (ö. 481/1185) vb. gibi âlimlerin değerlendirmelerini naklettiği birçok örnek de bulunmaktadır. (Mevsılî, 1342, s. 21 vd.)

Mevsılî, kullandığı 101 başlık altında bazen birkaç değerlendirmeye yer vermiştir. Bu şekilde 108 değerlendirmeyi sunduğu, bunlardan 38'inin kendisine ait, kalan 70 değerlendirmenin de nakilde bulunduğu âlimlere ait olduğu görülür. Bu durumu bir tablo üzerinde şöyle göstermek mümkündür.

\begin{tabular}{|l|l|}
\hline Değerlendirmeyi Yapan & Değerlendirme Sayısı \\
\hline Mevsilî (ö. 622/1225) & 38 \\
\hline Ebû Cafer el-Ukaylî (ö. 322/934) & 22 \\
\hline Ahmed b. Hanbel (ö. 241/855) & 17 \\
\hline Dârekutnî (ö. 385/995) & 7 \\
\hline İbnü'l-Cevzî (ö. 597/1201) & 4 \\
\hline Tirmizî (ö. 279/892) & 3 \\
\hline Buhârî (ö. 256/870) & 2 \\
\hline İbnü'l-Mübarek (ö. 181/979) & 1 \\
\hline Abdurrahman b. Mehdi (ö. 198/813) & 1 \\
\hline İbnü'l-Medînî (ö. 234/848) & 1 \\
\hline İbn Râhuye (ö. 238/853) & 1 \\
\hline Ebû Zür'a (ö. 264/878) & 1 \\
\hline Ebû Hâtim er-Râzî (ö. 277/890) & 1 \\
\hline İbrahim el-Harbî (ö. 285/899) & 1 \\
\hline İbnü'l-Münzir (ö. 318/930) & 1 \\
\hline İbn Hibbân (ö. 354/965) & 1 \\
\hline Ebû'l-Feth el-Ezdî (ö. 374/985) & 1 \\
\hline İbn Ŝâhin (ö. 385/996) & 1 \\
\hline Hâkim (ö. 405/1014) & 1 \\
\hline İbn Merdûye (ö. 410/1020) & 1 \\
\hline el-Hatîb (ö. 463/1071) & 1 \\
\hline Abdullah el-Ensârî (ö. 481/1185) & 1 \\
\hline & 108 \\
\hline
\end{tabular}

Yukarıdaki tabloya bakıldığında en çok değerlendirmeyi Ukaylî’den naklettiği görülür. Ukaylî gibi bir muhaddisin genelde kısa değerlendirmelerine yer veren Mevsılî’nin bu tercihi rastgele yapılmış bir seçim değildir. Zira çok eser verdiği kaydedilen Ukaylî’nin güvenilir bir muhaddis olduğu, hadisleri genelde ezberinden rivayet ettiği, hâfızasının sağlamlığını denemek isteyenlerin onun yanılmadığını gördükleri ifade edilmiştir. Günümüze ulaşan veya sadece isimleri bilinen eserleri Ukaylî’nin yoğun bir biçimde ricâl, cerh ve ta 'dîl alanlarında faaliyet gösterdiğgine işaret etmektedir. Hatta bu ilmin büyük otoriteleri olan Buhârî, Müslim, Ebû Zür`a er-Râzî, Ebû Hâtim er- 
Râzî vb. âlimlerden sonra yetişmiş metodolojik tasnif dönemine mensup ricâl âlimlerinden biri olduğu kaydedilmektedir. (Özafşar, 2012: 59)

Mevsılî’nin Ukaylî'den sonra en çok değerlendirmeyi Ahmed b. Hanbel'den aktardığına bakıldığında da Ahmed b. Hanbel'in hadis ilmindeki önemli yeri akla gelmektedir. Aynı zamanda Hanbelî mezhebinin imamı, önemli bir fakih olan bu âlimin hayatını en çok meşgul eden mesaisi hadis alanında olmuştur. Güçlü hâfızasıyla tanınan Ebû Zür'a, onun hıfzının kendisininkinden çok daha sağlam olduğunu itiraf etmiştir. Ahmed b. Hanbel'e göre, fakih sayılabilmek için iyi bir muhaddis olmak, en az dört yüz bin rivayeti ezbere bilmek ve sihhatinden emin olunmayan rivayetlerle fetva vermekten kaçınmak gerekir. Rivayetlere sahip olmayı yeterli görmemiş, ayrıca bu rivayetlerin mahiyetini bilmek gerektiğini ifade etmiştir. (Kandemir, 1989: 75-80)

Mevsılî’nnin üçüncü sırada en çok nakilde bulunduğu ismin Dârekutnî olduğu görülmektedir. Zekâsı, hafızası, ince anlayışı ve takvâsıyla döneminin önde gelen simalarından olan Dârekutnî’ye “emîrü'l-mü'minîn fi'l-hadîs" pâyesi verilmiştir. Ali b. Medînî gibi âlimler kendi devirlerinde nasıl birer hadis otoritesi iseler Dârekutnî’nin de kendi zamanında öyle olduğu ifade edilmiştir. Onun muhaddisler hakkındaki değerlendirmeleri çok önemsenmiş, hatta daha sonraki âlimler tarafından kesin hüküm olarak benimsenmiştir. Hatîb el-Bağdâdî’ye göre ilelü'l-hadîs, esmâü'r-ricâl gibi ilimler Dârekutnî ile sona ermiştir. (Çakan, 1993: 488-190)

Mevsı11̂̀'nin dördüncü sırada nakilde bulunduğu isim de İbnü'l-Cevzî'dir. 'Hâfızü'l-Irâk ve Nâsırü's-sünne" lakaplarıyla anılan İbnü'l-Cevzî, hadis aldığı şeyhlerinden ne zaman rivayette bulunduğunu çoğu zaman kaydetmiş, ardından onlardan duyduğu hadisin âlî ve nâzil oluşu, Sahîhayn'da yer alıp almadığı üzerinde titizlikle durmuştur. Ancak eleştirildiği noktalar da yok değildir. Örneğin hadis metinleriyle ilgili bilgisi takdir edilmiş, fakat sahih hadisleri belirlemede genellikle başarılı olamadığı ileri sürülmüştür. Zehebî (ö. 748/1348), İbnü'l-Cevzî'nin hadis ehlinin 1stılahındaki anlamıyla "hâfız" sayılamayacağını, hadislerin sahihini sahih olmayandan ayırma hususunda yeterli bilgiye sahip bulunmadığını ifade etmiştir. (Hatiboğlu, 1999: 550) Muhtemelen Mevsılî de aynı kanaatte olmuş olacak ki, mevzû hadis literatürü deyince ilk akla gelen isimlerden biri olan İbnü'l-Cevzî'den sadece dört (4) yerde nakilde bulunmuştur. Her ne kadar sadece İbnü'lCevzî'nin Kitâbü'l-Mevzû 'ât' 1 ndan faydalandığı ve ona bir şey katmadığı eleştirisi yapılmış olsa da (Kandemir, 2004a: 488-489) onun İbnü'l-Cevzî'den yalnızca dört yerde direkt nakilde bulunmuş olması dikkat çekmektedir.

Mevsılî’nin Buhârî'den iki yerde, hadis ilminin otoriteleri kabul edilen İbnü'l-Mübarek, Abdurrahman b. Mehdi, İbnü'l-Medînî, İbn Râhuye, Ebû Hâtim er-Râzî ve Ebû Zür'a gibi âlimlerden ise birer nakilde bulunduğu görülür. $\mathrm{Bu}$ da onun eserinin zayıf kaldığ değerlendirilebilir. 
Mevsılî’nin açtığı 101 başlığın konu dağılımını da şu şekilde göstermek mümkündür:

\begin{tabular}{|l|l|}
\hline Konu & Başlık Sayısı \\
\hline Namaz & 13 \\
\hline Yeme, İme ve Yiyecekler & 9 \\
\hline Zekat, Sadaka & 8 \\
\hline Abdest & 7 \\
\hline Kelamî Konular & 5 \\
\hline Fiten-Melahim & 5 \\
\hline Oruç & 3 \\
\hline Kur'ân & 3 \\
\hline Sahâbe & 3 \\
\hline Evlilik & 3 \\
\hline Saç Boyama & 3 \\
\hline İlim & 2 \\
\hline Faiz & 2 \\
\hline Diğer Konular & 35 \\
\hline & $\mathbf{1 0 1}$ \\
\hline
\end{tabular}

Yukarıdaki tablo incelendiğinde, Mevsı1ı̂’nin başlıklandırma yaparken âdetâ konu seçimindeki öncelikleri ortaya çıkmaktadır. Örneğin 101 başlık içerisinde insanın ibadet hayatıyla ilgili olan konularda (namaz, abdest, oruç, zekât) 31 başlık açtığı görülür. Ardından kişinin daha çok sosyal hayatını ilgilendiren hususlarda (yeme-içme, evlenme, ilim, saç boyama vb.) 17 başlığa yer verdiği ortaya çıkmaktadır. Kelâmî tartışmalar ve fiten-melâhim gibi konulara ise toplamda 10 başlık açmıştır. Geri kalan bölümler de değişik konulara tahsis edilmiştir.

Mevsı1̂̂ kendi yaptığı değerlendirmelerin yarısında hükümler vererek, o konuda sahih bir hadisin/rivayetin bulunmadığını ifade etmiştir. Bu tür değerlendirmeleri 19'u bulmaktadır. Geri kalan değerlendirmelerinde ise yine çok uzun sayılamayacak bazı açıklamaları verme yoluna gittiği görülmüştür. (Örneğin bkz. Mevsılî, 1342: s. 22, 23, 25, 27, 30, 33, 36 vb.)

Detaylara girdiği başlıklar içerisinde de özellikle 6 tanesinde daha fazla açıklama, yorum ve tartışmaya yer verdiği tespit edilmiştir. Bunlara bakacak olursak;

1-Süt, bal ve baklanın övülmesi ile ilgili başlığın altında, o konuda sahih bir haberin vârid olmadığını bildirdikten sonra şöyle bir açıklama yapma ihtiyacı hissetmiştir: "Zındıklar buna benzer hadisleri, İslam'a leke sürmek ve Hz. Peygamber'i (sas) yalanlamak gayesiyle uydurmuşlardır." (Mevs1lî, 1342: 39)

2- Beyaz saçın renginin değiştirilmesi konusuna ise nispeten daha geniş yer ayıran müellif, Hz. Ebubekir ve Hz. Ömer'in saçlarını sade kına ile boyadıklarını kaydetmektedir. (Bkz. Buhârî, "Fedâil", 103) Ardından Hz. Hüseyin'in de saçının boyalı olduğunu bildiren bir rivayet (Bkz. Buhârî, "Fedâil", 22) sunan Mevsılî, Ebû Dâvud'un Sünen'inde geçen şöyle bir rivayeti aktarır: "Ahir zamanda siyah renkle saçını boyayacak insanlar çıkacaktır. Onlar cennetin kokusunu alamazlar." (Ebû Dâvûd, "Tereccül”, 20) Öte yandan Hz. Hasan, Hz. Hüseyin, Sa'd b. Ebî Vakkâs ve tâbiûndan birçok kişinin saçını siyaha boyadığı bilgisini de eklemektedir. (Mevsılî, 1342: 41-42)

Tabii yukarıda verilen rivayetler arasında bir ihtilaf durumu ortaya çıkmaktadır. Saç boyama mutlak olarak yasaklanmış mıdır? Sadece kına ile boyamak mı caizdir? Siyah rengin dışında bir renkle boyamak caiz midir? gibi sorular akla gelmektedir.

Mevsılî beyaz saçın değiştirilmesi konusunda genel bir hüküm olarak "bu konuda -yani yasaklanması noktasında- sahih bir hadis bulunmamaktadır, Ebû Kuhâfe için söylenen 'Saçını 
boyayın, siyahtan sakının' (Ebû Dâvûd, “Tereccül”, 18) sözü hariç” ifadesinden sonra iki noktanın önemine vurgu yapmaktadır:

1-Yukarıda da zikredilen Buhârî rivayetleri kaynak itibariyle başka rivayetlerden önceliklidir.

2-Bu iş haram olsaydı Hz. Hasan ve Hz. Hüseyin gibi sahâbîler yapmazlardı.

Burada Ebû Hüreyre'den nakledilen "Yahudiler ve Hristiyanlar saçlarını boyamazlar, siz aksini yapın, boyayın" (Buhârî, "Enbiya", 50; Müslim, "Libâs", 80) rivayetini eklemeyi de ihmal etmemiştir. (Mevsılî, 1342: 42) Mevsılî, bu konuda mutlak bir yasak olmadığını, bazı durumlarda ve belli şartlarda yasak konulduğunu ispatlama çabası içerisine girmiş görünmektedir. (Mevsılî, 1342: 42; Krş. Agitoğlu, 2015: 260) Müellifin ibadet ile ilgili veya kelâmi konulara değil de böyle bir konuya geniş yer vermesi, ayrıca tartışmalara girmesi de ilginçtir.

3- Sağ ele yüzük takma konusuna da kısmen geniş yer veren Mevsılî (Mevsılî, 1342: 42), bu konuda sahih bir hadisin gelmediğini belirttikten sonra, Dârekutnî'den şunu nakleder: Bu hususta Enes'ten farklı rivayetler gelmiştir. Hz. Peygamber'in sol ele yüzük taktığı da vâkidir." Burada vurgulanan şey aslında onun hem sağ hem sol ele yüzük taktığı hususudur. (Bkz. Buhârî, "Libâs", 46-55; Nesâî, "Zînet", 48; Tirmîzî, "Libâs", 16; Ebû Dâvûd, "Hâtem”, 5)

4-Bir başka yerde "Kadın mürtedin öldürülmeyeceği ile ilgili bab" başlığı altında müellif, Dârekutnî' nin, o konuda sahih bir hadis bulunmadığını belirttiğinin ifade etmiştir. Ancak kendisi, Sahihayn'da bunun aksi yönde bir hadis bulunduğunu bildirmektedir: "Dinini değiştireni öldürünüz." (Mevsılî, 1342: 44 ) Mevsılî’nin el-Muğnî'de verdiği bilgilerin üçte birini eleştirdiğini söyleyerek bu kitabın muhtevasına yönelik tenkitlerini 101 konuda toplayan el-Eserî de Cünnetü'l-mürtâb isimli eserinde bu konuyla ilgili herhangi bir açılama ve yorumda bulunmamıştır. (Eserî, 1994: 507) Ancak biz bu rivayeti Sahihayn'da değil de sadece Buhârî' de tespit edebildik. (Bkz. Buhârî, Cihad, 147)

5- Karaborsacılık başlığı altında da (Mevsılî, 1342: 45) o konuda sahih hadis bulunmadığını belirten müellif, "Ancak günahkâr olan karaborsacılık yapar" (Müslim, Müsakât, 129-130) rivayetini istisna etmektedir. Devamında şöyle bir izahat verme yoluna gitmektedir: Bu hadisin ravileri arasında Said b. el-Müseyyeb bulunmaktadır. O hadisi Ma'mer b. Ebi Ma'mer'den almıştır. Hâlbuki Said de Ma'mer de karaborsacı idiler. Nitekim İbnu'l-Müseyyeb anlatıyor: 'Ma'mer b. Ebî Ma'mer dedi ki: Resûlullah (sas) şöyle buyurdu: 'Ancak günahkâr olan ihtikar yapar'. Said b. el-Müseyyeb'e, Ama sen de ihtikâr yapıyorsun, denildiğinde, bu hadisi rivayet eden Ma'mer de ihtikâr yapıyordu, diye cevap vermiştir. (Müslim, Müsâkat: 129; Ebû Dâvud, Büyû: 49; Tirmizî, Büyû: 40).

Burada karışık bir durumun olduğuna âdetâ dikkat çeken müellif şu açıklamayı yapmayı gerekli görmüştür: "Ravi rivayet ettiği hadise muhalefet ederse bu durum ya neshe ya hadisin zayıflığına delalet eder. Ayrıca ihtikâr yani karaborsacılık, bir bölgenin insanlarına zarar verdiği zaman haram olur demişlerdir.” (Mevsılî, 1342: 45) Bunu derken Mevsılî, sanki ihtikârın belli bazı durumlarda meydana geleceğini, belki de toplumun zaruri ihtiyaçlarının ve bunun derecesinin söz konusu işin karaborsa olup olmayacağını tayin edeceğini belirtmektedir.

6- Kur'ân'1 lahn (hata) ile okumanın haram oluşuna dair de bir başlık açan müellif, bu konuda sahih bir hadisin bulunmadığını ifade etmiştir. Ardından Hz. Peygamber'in Fetih günü Mekke'ye girerken Fetih suresini sesini boğazda titreterek okuduğunu haber veren bir rivayet sunmuştur. (Buhârî, “Tefsir", 48(1); Müslim, "Salâtü'l-müsafirîn”, 237) Hadisin ravisinin rivayette geçen tercî' kavramını "a-aa-aa diyerek uzatma" şeklinde açıkladığını nakletmiştir. (Mevsılî, 1342: 48) Burada da müellif Kur'ân-1 Kerîm'in tercî' ile okunabileceğini, belli bir ahenk ile kıraatinin caiz olduğunu ifade etmekte, konu başlı̆ğ ile bağlantı kurulduğunda da sanki kasıtlı olmadıktan sonra yanlış okumanın insanı günaha sokmayacağı hususunu vurgulamaktadır. 
Yukarıda da belirttiğimiz gibi müellif bu altı başlık altında detaylı açıklamalara ve bazen tartışmalara girmiş, bunların dışındaki başlıkların altında ise çok kısa açıklamalar veya bir cümlelik hükümler vererek konuları işleme yöntemini seçmiş görünmektedir. Ancak tafsilatlı izahlara yer verdiği bu altı başlığı neye göre seçtiğini bilemiyoruz. Ayrıca İtikad ve İbadet gibi ana konular dururken bu altı başlıktaki konuları geniş açıklamalarla zenginleştirmesi de ilginç ve dikkat çekici durmaktadır.

\section{Sonuç}

Hadis usûlü ilminde mevzû hadis konusu, dinin ikinci ana kaynăg 1 olan hadislerin tespiti meselesi ile yakından ilgili olmuştur. Sıhhatin tespit edilmesi ameliyesinin ana amaçlarından biri, zaten hadislerden uydurulmuş olanları ayıklamaktır.

Titiz bir şekilde çalışan muhaddislerin usûl kitaplarında bu konuya önemle yer verdikleri ve bu alanda müstakil eserler yazarak bir edebiyat ortaya çıkardıkları bilinen bir husustur.

Mevzû hadisler muhaddisler tarafından çeşitli metotlarla bir araya getirilmiştir. Bu alanda birçok esere imza atılmıştır. Bu eserlerden bir tanesi de Mevsılî'nin el-Muğnî ani'l-hıfzi ve'l-kitab adlı çalışmasıdır.

Çalışmamıza konu olan eserinde sened ve metinleri zikretmeden, hangi konularda sahih hadislerin bulunmadığı veya hangi konularda Hz. Peygamber'den rivayet gelmediğini belirtmektedir. Müellifin, öğrencilere ve hadisle ilgilenme firsatı bulamayan ve çalışan kişilere kısaca bilgi vermek ve onları hadise yönlendirmek için seçtiği bu metot dikkat çekicidir. Müellifin pratik olarak, kestirmeden bilgi sunmayı amaçladığı belirtilerek tekrarlara girmediği ve eserini bablara ayırdığ girişte belirtmiştir.

Mukaddimeden hemen sonra müellifin metodu hakkında önemli bir ayrıntıya dikkat çekilen

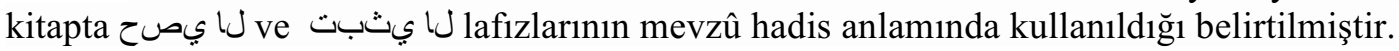

Mevsılî, eserini 101 bab şeklinde düzenlemiştir. Kısa değerlendirmelerinin yanında bazen de değerlendirme yapmak yerine başka bir âlimin yaptığı değerlendirmeyi nakletmekle yetinmektedir. Bazen rivayeti nakleder, ancak o rivayetin mevzû olduğu kaydını da ekler.

Mevsılî’nin başlıklandırma yaparken konu seçimindeki öncelikleri ortaya çıkmaktadır. Örneğin 101 başlık içerisinde insanın ibadet hayatıyla ilgili olan konularda (namaz, abdest, oruç, zekât) 31 başlık açtı̆̆ görülür. Ardından kişinin daha çok sosyal hayatını ilgilendiren hususlarda (yeme-içme, evlenme, ilim, saç boyama vb.) 17 başlı̆ga yer verdiği ortaya çıkmaktadır. Kelâmî tartışmalar ve fiten-melahim gibi konulara ise toplamda 10 başlık açtığı görülür. Geri kalan bölümler de değişik konulara tahsis edilmiştir.

Mevsı11 kendi yaptığı değerlendirmelerin yarısında hükümler vererek, o konuda sahih bir hadisin/rivayetin bulunmadığını ifade etmiştir. Bu tür değerlendirmeleri 19'u bulmaktadır. Geri kalan değerlendirmelerinde ise yine uzun sayılamayacak bazı açıklamaları verme yoluna gittiği görülmüştür.

Müellifin detaylara girdiği başlıklar içerisinde 6 tanesinde daha fazla açılama, yorum ve tartışmaya yer verdiği görülmüştür. Mevsılî, bu altı başlık altında detaylı açıklamalara ve bazen tartışmalara girmiş, bunların dışındaki başlıkların altında ise genelde bir cümlelik hükümler vererek konuları işleme yöntemini seçmiştir. İtikad ve İbadet gibi ana konular dururken bu altı başlıktaki konuları geniş açıklamalarla zenginleştirmesi de ilginç durmaktadır.

Ebû Cafer el-Ukaylî, Ahmed b. Hanbel, Dârekutnî, Ebû Hâtim er-Râzî, İbnü'l-Mübarek, İbnü'l-Cevzî, İshâk b. İbrahim el-Hanzalî, Tirmizî, Ebû Zür'a, Buhârî, İbnü'l-Medinî, Hâkim, el- 
Ezdî, Abdullah el-Ensârî vb. gibi âlimlerin değerlendirmelerini naklettiği birçok örnek bulunmaktadır.

Bazı âlimler tarafından eleştirilmişse de bu eserin, ilimle iştigal etmeye imkân ve firsat bulamamış halka yönelik bir aydınlatma ve bilinçlendirme görevini yerine getirdiğini söylemek mümkündür. Bu anlamda önemli bir yere sahip olduğu söylenebilir.

\section{KAYNAKÇA}

Agitoğlu, N. (2015). Hadis ve Bă̆lam. İstanbul: Kitabi Yayınları.

Belâzûrî, (1987.) Futûhu'l-buldân, Tahk. Abdullah Enîs et-Tabbâ', Beyrut: Müessesetu'l-Maârif.

Buhârî, (1987). el-Câmiü's-sahîh, I-VI, Beyrut: Dâru İbn Kesîr.

Çakan, İ.L. (1993). "Dârekutn̂̂”, DİA, VIII, 488-490, İstanbul: TDV Yayınları.

Ebû Dâvûd, (Trs.). Sünen, I-IV, Beyrut: Dâru'l-kitâbi'l-Arabî,

Eserî, Ebû İshak el-Huveynî. (1994). Cennetü 'l-mürtâb, I-II, Beyrut: Dâru'l-kitabi'l-Arabî.

Hatiboğlu, İ. (1999). “İbnü'l-Cevzî, Ebü'l-Ferec”. DİA, XX, 550, İstanbul: TDV Yayınları.

İbn Hacer, (2001). Nüzhetü'n-nazar fî tavdîhi Nuhbeti'l-fiker, Tahk. Abdullah b. Dayfullah, Riyad.

(1401) el-Kavlü'l-müsedded fí'z-zebbi ani'l-Müsned li'l-Imam Ahmed, Kahire: Mektebetü İbn Teymiyye.

İbnü's-Salâh, (Trs.). Ulûmu'l-Hadîs, Tahk. Nureddin Itr, Beyrut: Dâru'l-fikr.

Kandemir, Y. (1989). “Ahmed b. Hanbel”. DIA, II, 75-80. İstanbul: TDV Yay.

.. (2004). "Mevs11î, Ömer b. Bedr". DIA, XXIX, 488. İstanbul: TDV Yay.

., (2004). "Mevzû", DİA, XXIX, 493. İstanbul: TDV Yay.

, (1997). Mevzû Hadisler Menşei Tanıma Yolları Tenkidi İstanbul: İFAV.

Kâtip Ç. (Trs.). Keşfu'z-zunûn an esâmî'l-kütübi ve'l-fünûn, I-II, Beyrut: Dâru ihyâi't- türâsi'lArabî.

Koçyiğit, T. (1967). Hadis Usulü, Ankara: A.Ü.İ.F.

Mevsılî, Ebû Hafs Ömer b. Bedr. (Trs.). el-Muğnî ani'l-hıfzi ve'l-kitab, Kahire: Cem'iyetü neşri’lkütübi'l-Arabiyye.

Muslim b. el-Haccâc el-Kuşeyrî. (Trs.). el-Câmiü's-sahîh, I-V, Beyrut: Dâru ihyâi't-türâsi'l-Arabî.

Nesâî, E. (1992). es-Sünen, İstanbul: Çağrı Yay.,

Özafşar, M. E. (2012). “Ukaylî”. DİA, XLII, 59. Ankara: TDV Yay.

Suyûtî, C. (Trs.). Tedrîbü'r-râvî, Dammam: Dâru İbni’l-Cevzî.

Tirmizî, E. (Trs.), es-Sünen, Beyrut: Daru İhyai’t-Türasi'l-Arabî.

Uğur, M. (1992). Ansiklopedik Hadis Terimleri Sözlüğü, Ankara: TDV Yay.

Yıldırım, E. (2017). Sahih Hadis Bulunmayan Konular, İstanbul: Otto Yay. 